\title{
Ellipsis
}

Volume 44

Article 36

2017

\section{Avant Garde}

Ben Aleshire

University of New Orleans

Follow this and additional works at: https://scholarworks.uno.edu/ellipsis

\section{Recommended Citation}

Aleshire, Ben (2017) "Avant Garde," Ellipsis: Vol. 44 , Article 36.

DOI: https://doi.org/10.46428/ejail.44.36

Available at: https://scholarworks.uno.edu/ellipsis/vol44/iss1/36

This Visual Art is brought to you for free and open access by the Department of English and Foreign Languages at ScholarWorks@UNO. It has been accepted for inclusion in Ellipsis by an authorized editor of ScholarWorks@UNO.

For more information, please contact scholarworks@uno.edu. 


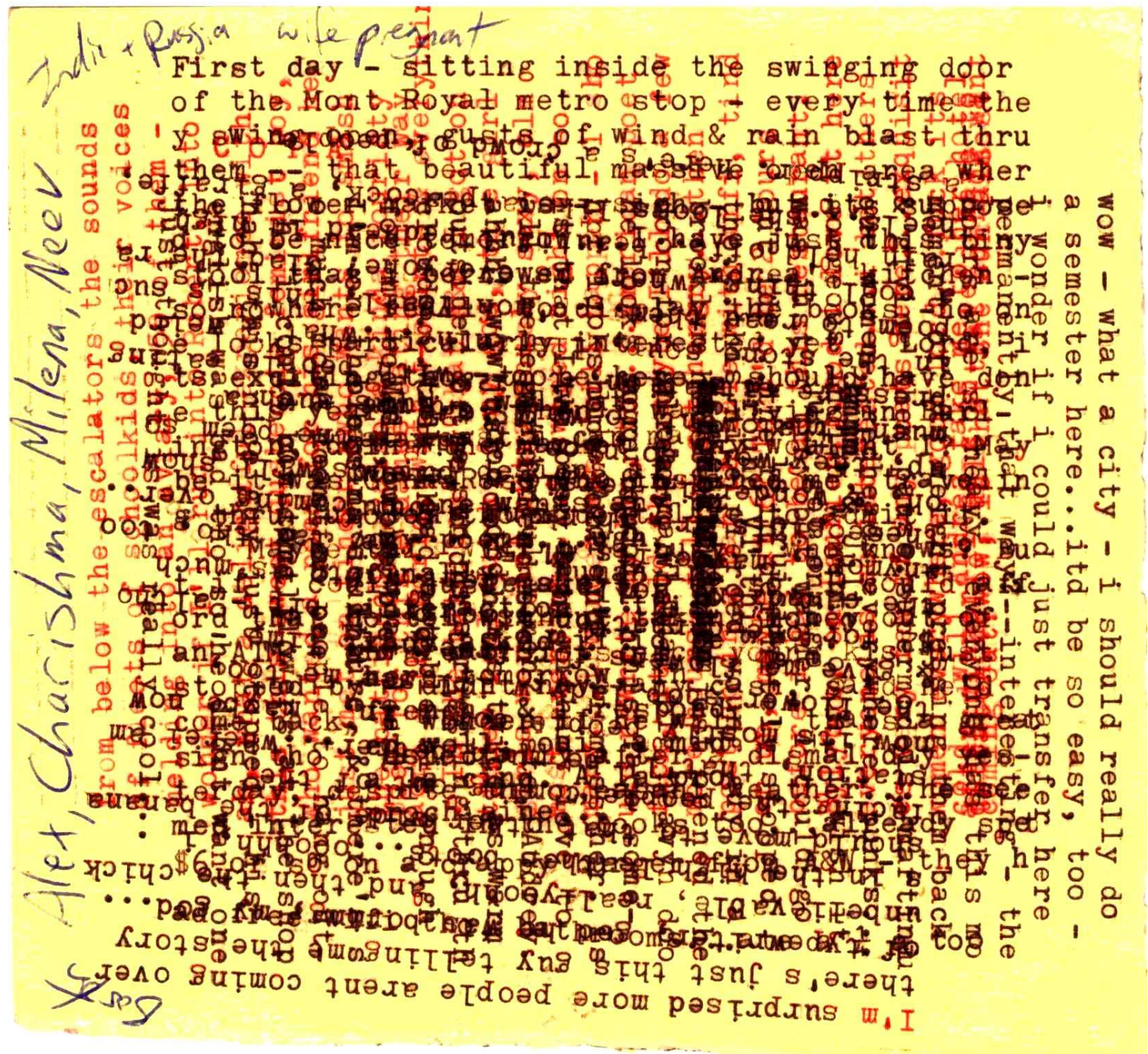

